\title{
The Effects of Green Brand Positioning, Green Brand Knowledge, and Attitude towards Green Brand on Green Products Purchase Intention
}

\author{
Lendy Aulina ${ }^{1}$, Elevita Yuliati ${ }^{1 *}$ \\ ${ }^{1}$ Faculty of Economics and Business, Universitas Indonesia \\ Email: elevitaprayitno@gmail.com
}

\begin{abstract}
This research is based on Huang et al. (2014), and aim to analyze the influence of green brand positioning, green brand knowledge and attitude towards green brand to green purchase intention. While Huang, Yang and Wang focused on green cars purchase intention, this research focuses on personal care and cosmetics products. The object of this research is The Body Shop, a brand widely known for its green activities. The 347 respondents were consumers who have never bought The Body Shop previously and lived in Jakarta and greater area (Jabodetabek). The data was analyzed with Structural Equation Modelling, using LISREL 8.51 statistical software. The results showed that green brand positioning, while does not influence attitude toward green brand, has positive effects on green brand knowledge. Green brand knowledge positively influences attitude toward green brand, and finally, attitude toward green brand positively influence green purchase intention.
\end{abstract}

Type of paper: Empirical

Keywords: green brand; green product; brand positioning; brand knowledge; brand attitude; purchase intention

\section{Introduction}

Sustainability development has become an important topic in the world since Brundtland Commission in 1987 and Earth Summit in 1992 (Lubin and Esty, 2010). Sustainability now has become an important goal for companies. With growing consumers' attention toward the environment, many companies try to develop intense communication on how their business manage sustainability activities (Raska and Shaw, 2012). The environment issue has also affecting consumers' trend in beauty and personal care products. A survey conducted by Euromonitor in 2013 showed that beauty and personal care has become a potential product category for environmentally friendly brands (Euromonitor International, 2013).

Previous researches has used the concept of green brand, for example in Patrick, Ibanez, and Sainz (2005), which established the positive influence of Green Brand Positioning (GBP) on attitude toward brand. Another research by Rios et al. (2006) showed how association with environment positively influence brand attitude. However, Oliver and Lee (2010) proposed 
that previous research were not comprehensive enough to show how Green Brand Positioning influenced Green Purchase Intention (GPI) since those researches overlooked the role of green attributes as motivating factors in purchasing green products.

Based on Huang, Yang, and Wang (2014), this research is intended to examine the influence of Green Brand Positioning, Green Brand Knowledge, and Attitude toward Green Brand on purchase intention of green brand in personal care and beauty product category. This research focused on a single brand, The Body Shop. Huang, Yang and Wang (2014) used the environmentally friendly car brands as the research object. Another research by Suki (2016) used the same variables as Huang, Yang and Wang to examine their influence on organic food purchase intention. This research will use Huang, Yang and Wang (2014)'s research variables to examine their influence on cosmetic and personal care category.

The Body Shop is an international cosmetic and personal care company established by Anita Roddick in 1976 in Brighton, England. Their green activities have become the company's core values. One of the most differentiating characteristics of The Body Shop is its pursuit of social and environmental change (Aaker, 1996).In 1989, The Body Shop Foundation was established as a way on consolidating company giving. The foundation funds innovative social and environmental projects around the world. (Building for the Future, Values Performance Report, 2015). The Body Shop entered Indonesian market in 1992 through PT Monica Hijau Lestari as the sole distributor.

\section{Literature Review}

American Marketing Association defined brand as a "name, term, sign, symbol, or design, or a combination of them intended to identify the goods and services of one seller or group of sellers and to differentiate them from those of competition." (Keller, 1998). On the other hand, the definitions of green brand, or even of green product, are still slightly different from one academic literature to the others. For example, Liu and Wu (2009) in Durifet al. (2010) defined green products as "products whose functions or ideas deal with the process of material retrieval, production, sales, utilization and waste treatment available for recycling, reduced pollution and energy saving". Meanwhile, Albino, Balice and Dangelico (2009) defined green products as "product designed to minimize its environmental impacts during its whole lifecycle" (Durifet al. 2010). Due to environmental issues, companies have accepted green brands as part of their strategy to gain competitive advantage (Rios et al., 2006).

\subsection{Green Brand Positioning}

Brand positioning can be utilized as a tool in gaining a company's competitive advantage (Clancy and Trout, 2002). Keller (1998) defined brand positioning as the activities that a company use to determine a location in consumer minds by reviewing information to design the desired brand awareness image, and finally gives consumers a strong reason why they should buy a certain brand. Green brand positioning focuses on how communication and attributes of a brand is different from its competitors due to the use of environmentally-related attributes. There are three parts of green brand positioning: functional positioning, green positioning, and emotional positioning.Functional positioning refers to the functions of brand attributes as a mediator to convey environmentally-related messages to consumers (Hartmann et al., 2005). Green positioning is included as a part of green brand positioning since it is an important 
factor to support green branding strategy (Coddington, 1993 in Patrick et al., 2005). Emotional positioning is important to transfer affective contents of brand attributes to gain consumers' emotional responses (Edell and Burke, 1987 in Mattheset al., 2013).

\subsection{Green Brand Knowledge}

According to Alba and Hutchinson (1987) in Larocheet al. (2001), brand knowledge is the accumulated experience in directly or indirectly using a brand, so that consumers record the identity of the brand (e.g. logo, color and name). For an environmentally friendly product, green brand knowledge is a process to provide information which changes consumer behavior to be more environmentally friendly (Frank, 1988 in Bhaskaranet al., 2006). Keller (1993) classified green brand knowledge into two dimensions: green brand awareness and green brand image.

A company with an environmentally friendly brand in its portfolio should conduct green marketing to raise awareness to the brand (Chen and Chang, 2012). To raise awareness, the company can provide information about the brand's environmental concerns (Martin and Simintiras, 1995). The second dimension of green brand knowledge is green brand image, which is defined as "a collection of perceptions about a certain brand in the minds of consumers which related to the brand's commitment in protecting the environment" (Chen, 2008).

Green brands need communication and differentiating factors which emphasize environmental concerns to secure a position in consumers' mind and to gain competitive advantage against the competitors (Rios et.al., 2006). Communication efforts for green brands must result in brand awarenessand consumers' interest (Marcus and Fremeth, 2009). Green positioning strategy must focus on providing information through environmentally friendly product and brand attributes so that consumers understand the inter-relatedness of the brand and environmental concerns (Rios et al., 2006). Meanwhile, brand image is formed through marketing communication strategy (Seitzet al.,2010). Green brand positioning strategy can be executed through marketing communications which shape a positive perception in consumers' minds. This positive perception will result in better green brand knowledge through brand awareness and image. Based on this explanation, the hypothesis developed is:

H1: Green Brand Positioning (GBP) positively influence Green Brand Knowledge (GBK)

\subsection{Attitude toward Green Brand}

Lee (2008) defined attitude toward green brand as a concept developed from consumers' evaluation process and rational judgment toward the green brand. Companies' efforts to convey environmentally friendly attribute to consumers will help consumers to decide between brand alternatives (Rios et al., 2006). Consumers' environmental concern is positively related to their behavior towards green brand (Swenson and Wells, 1997 in Huang et al., 2014), especially when consumers realized that companies' activities matched their green brand positioning (Becker-Olsenet al., 2006).

Knowledge and awareness to protect the environment have become major influences on consumers' attitude towards green brand. A study in Egypt (Mostafa, 2007 in Huang, et.al., 2014) concluded that consumers' knowledge on environmental issues is an important factor to 
influence environmental friendly attitudes. Aaker and Joachimsthaler (2002) stated that brand awareness and positive brand image will influence consumers' brand attitude toward a green brand.

Based on the explanation, the hypotheses developed are:

H2: Green Brand Positioning (GBP) positively influence Attitude toward Green Brand (AGB)

H3: Green Brand Knowledge (GBK) positively influence Attitude toward Green Brand (AGB)

\subsection{Green Purchase Intention}

Green purchase intention is defined as consumers' likelihood to purchase green brands as their efforts to fulfil their needs (Netemeyer, et.al., 2001 in Fuchs and Diamantopoulus, 2010). A positive attitude towards green brand will influence green purchase intention (Chen, 2012). Consumers who have concerns about the environmental issues will include himself or herself to become problem solutions by changing their consumption patterns (Rehman and Khyzer, 2013). When a consumer realized the presence of green attributes of a brand and purchase the brand afterwards (Oliver and Lee, 2010), then the consumer is classified as green consumers, defined as responsible consumers because they use their purchasing power to make changes (Moisander, 2007). Mostafa (2007) in Huanget.al., (2014) concluded that consumers with high level of attitude toward green product will have a strong likelihood toward green purchase intention. Based on the explanation, the hypothesis developed is:

H4. Attitude toward Green Brand (AGB) positively influence Green Purchase Intention (GPI) Based on the aforementioned literature review, conjectures and hypotheses, the following research framework is posited:

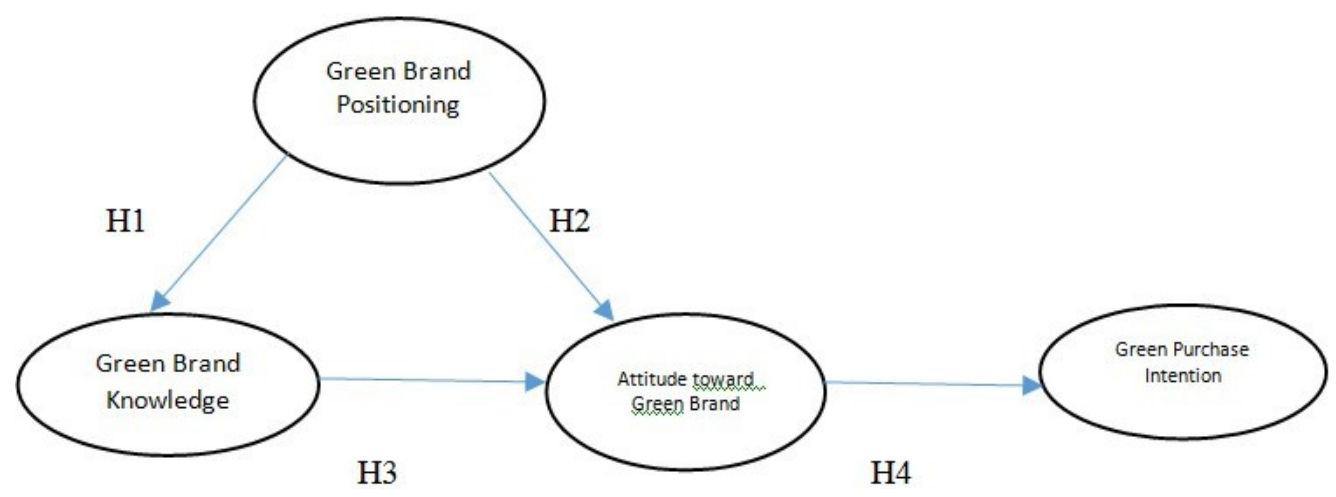

Figure 1. Proposed Theoretical Framework

\section{Research Methodology}

The data was collected through distribution of research questionnaire. Respondents are men and women who have never bought The Body Shop previously and live in Jakarta and the greater area (known as Jakarta, Bogor, Depok, Tangerang and Bekasi or Jabodetabek Area). The 
sampling method used was the purposive, non-probability sampling. The research questionnaire was distributed online. After screening process, a total of 347 questionnaires was used.

\subsection{Questionnaire Development}

The research questionnaire used a 5-point Likert Scale, ranging from $1=$ Strongly Disagree to $5=$ Strongly Agree. Measurements for Green Brand Positioning was adapted from Patrick, et.al., (2005) which comprises of thirteen items, classified into three dimensions: functional positioning, green positioning, and emotional positioning. Green Brand Knowledge was measured using nine items adapted from Keller (1993), classified into green brand awareness and green brand image. Attitude toward Green Brand was measured using 8 items from Patrick, et.al., (2005), classified into cognitive and emotional elements. Measurements for Green Purchase Intention was three items adapted from Pavlou (2003) and Chang and Chen (2008) in Huang, et.al., (2014).

\subsection{Statistical Technique}

The data was analyzed using Structural Equation Modelling (SEM). LISREL 8.51 software was used to assist in data analysis. The data analysis in SEM was classified into measurement model and structural model analysis. The goodness of fit test showed the result of 0.071 for Root Mean Square Error of Approximation (RMSEA), 0.95 for Goodness-of-Fit Index (GFI), 0.92 for Adjusted Goodness-of-Fit Index (AGFI), and 0.97 for Comparative Fit Index (CFI). These results showed good fit so it can be concluded that the research model is adequate.

\section{Results}

Descriptive analysis was used to obtain demographic profiles of respondents. The majority of respondents were women (86\%), age 17-21 year old (79\%), high school or college students $(84 \%)$. Most of the respondents are currently resided in Depok, West Java area $(29 \%)$. The majority of respondents spend less than IDR 250.000 (approximately USD 19) for every purchase of cosmetics and personal care (71\%). The average monthly spending of $47 \%$ respondents, exclusive of routine expenses such as rent and transportation, is IDR 1 million (approximately USD 74). The main information sources for personal care and cosmetics choices are recommendation from family and friends (37\%) and recommendations from beauty bloggers/vloggers (24\%).

\subsection{Measurement Model Analysis}

The validity of each questionnaire item was measured using t-value and Standardized Loading Factor (SLF) of each indicator. Rigdon and Ferguson (1991) and Dollet al. (1994) stated that an item is valid if the loading factors $>1.645$ (one-tailed), while according to Hairet.al., (1995) in Igbariaet al. (1997), an item is valid if the SLF is $>0.50$. Reliability of each variable was measured using Composite Reliability (CR) and Variance Extracted (VE) measures. The reliability of each variable is considered as tolerable when $\mathrm{CR}$ is $>0.70$ and $\mathrm{VE}$ is $>0.50$. (Hair, Anderson, Tatham and Black, 1998). The data analysis process also employed Latent Variable Score (LVS), which is a model simplification by transforming the values of several indicators into one new value according to their respective dimensions. 
Table 1. Reliability and Validity of Measurement Model

\begin{tabular}{|c|c|c|c|c|c|}
\hline Latent Variables & Indicators & T-Value & SLF & $\mathbf{C R}$ & VE \\
\hline \multirow{3}{*}{ Green Brand Positioning (Gbp) } & Mean_FP & 14.83 & 0.70 & \multirow{3}{*}{0.75} & \multirow{3}{*}{0.50} \\
\hline & Mean_GP & 10.53 & 0.55 & & \\
\hline & Mean_EP & 18.44 & 0.85 & & \\
\hline \multirow{2}{*}{ Green Brand Knowledge (Gbk) } & Mean_GBA & 17.57 & 0.81 & \multirow{2}{*}{0.82} & \multirow{2}{*}{0.69} \\
\hline & Mean_GBI & 19.26 & 0.86 & & \\
\hline \multirow{2}{*}{$\begin{array}{l}\text { Attitude Toward Green Brand } \\
\text { (Agb) }\end{array}$} & Mean_CE & 14.20 & 0.70 & \multirow{2}{*}{0.78} & \multirow{2}{*}{0.65} \\
\hline & Mean_EE & 19.82 & 0.90 & & \\
\hline \multirow{3}{*}{ Green Purchase Intention (Gpi) } & GPI1 & 19.30 & 0.86 & \multirow{3}{*}{0.89} & \multirow{3}{*}{0.75} \\
\hline & GPI2 & 20.13 & 0.88 & & \\
\hline & GPI3 & 19.22 & 0.85 & & \\
\hline
\end{tabular}

Table 1 showed that all t-values and SLF scores are still within the tolerable limit. The lowest scores for t-value (10.53) and SLF (0.55) are still exceeding the minimum scores set for validity criteria. The reliability test also showed that all variables are reliable. The lowest scores for CR $(0.75)$ and VE $(0.50)$ are still within the limit for reliability criteria. It can be concluded from this result that all items in latent variables in the research model are valid and reliable.

\subsection{Structural Model Analysis}

The next step is to perform the structural model analysis. The relationship between constructs in the research model will be measured using $t$-value to identify influence between latent variables. The t-value score must be $>1.645$ (one-tailed) in order to accept the proposed hypothesis.

The results in Table 2 showedthat only one hypothesis was not supported. Green Brand Positioning does not directly influence Attitude toward Green Brand, with the t-value score of -0.23 , far below the minimum limit of 1.645. However, Green Brand Positioning still indirectly influence Attitude toward Green Brand via Green Brand Knowledge. The resulted structural model is shown in Figure 2.

Table 2. Structural Model Analysis

\begin{tabular}{|c|c|c|c|}
\hline No & Hypothesis & T-Value & Conclusion \\
\hline 1 & $\begin{array}{c}\text { Green Brand Positioning } \rightarrow \\
\text { Green Brand Knowledge }\end{array}$ & 15.94 & H1 supported \\
\hline 2 & $\begin{array}{c}\text { Green Brand Positioning } \rightarrow \\
\text { Attitude toward Green Brand }\end{array}$ & -0.23 & H2 not supported \\
\hline 3 & $\begin{array}{c}\text { Green Brand Knowledge } \rightarrow \\
\text { Attitude toward Green Brand }\end{array}$ & 1.99 & H3 supported \\
\hline 4 & $\begin{array}{c}\text { Attitude toward Green Brand } \\
\text { Green Purchase Intention }\end{array}$ & 11.46 & H4 supported \\
\hline
\end{tabular}




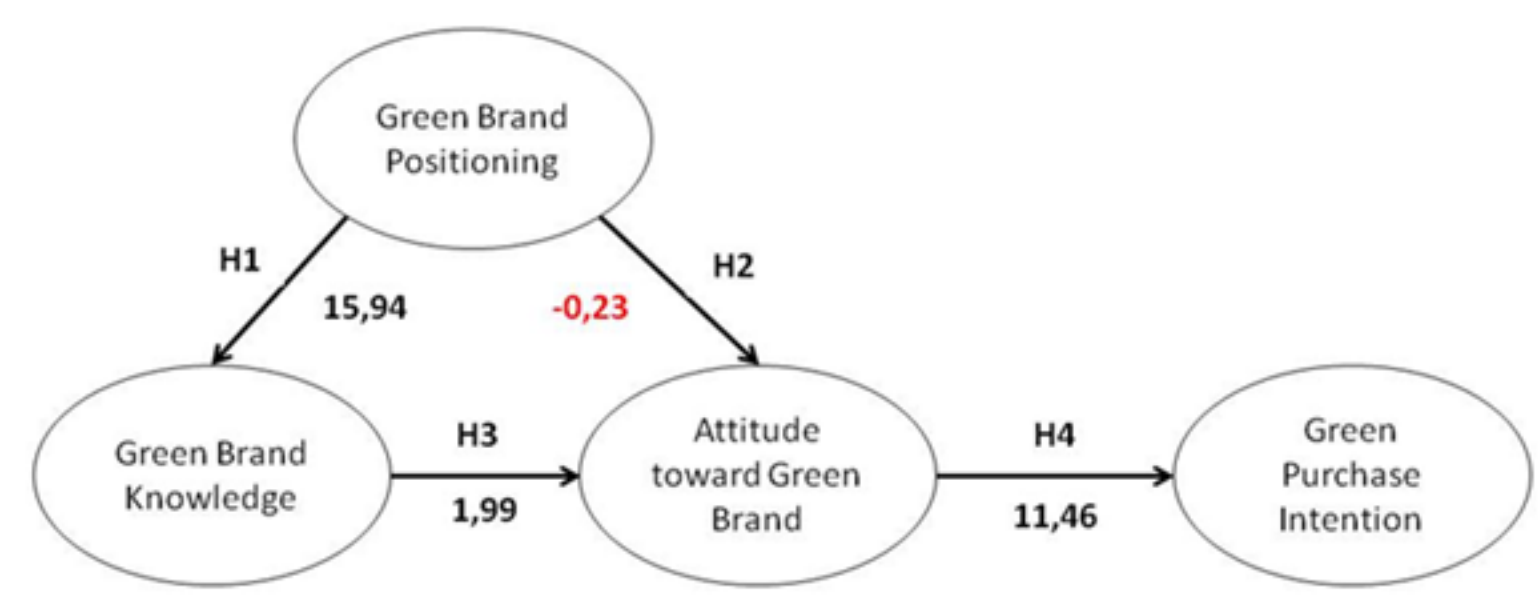

Figure 2. Resulted Structural Model

\section{Discussion}

The data analysis results showed that Green Brand Positioning, Green Brand Knowledge, and Attitude toward Green Brand influenced Green Purchase Intention for The Body Shop, whether directly or indirectly. Green Brand Positioning influenced Green Brand Knowledge with t-value score of 15.94. This result emphasized the importance of differentiating a company's brand from other competitors by having a clear positioning strategy (Huang, et.al., 2014). Green Brand Positioning significantly influence Green Brand Knowledge through a focused and integrated communication strategy to convey green positioning messages in order to inform consumers on brand's connection with environmental concerns (Rios, et.al, 2006).

Acloser examination to the result showed that Green Brand Positioning does not have significant influence on Attitude toward Green Brand. The t-value score is -0.23. Previous research showed different result, in which Green Brand Positioning positively influenced Attitude toward Green Brand (Huang, et.al., 2014). While Green Brand Positioning does not have significant influence on Attitude toward Green Brand, Green Brand Positioning significantly influence Green Brand Knowledge, and in turns, Green Brand Knowledge has positive and significant influence on Attitude toward Green Brand (t-value 1.99). It might be concluded from this result that the positioning of The Body Shop as a green brand is interpreted by consumers as a series of information on environmentally related issues. The information, in turn, would form consumers' knowledge about the brand, which then would determine their attitude toward The Body Shop. The mere positioning strategy, conveyed throughThe Body Shop's marketing communication, could not directly influence consumers' attitude toward the brand because consumers need to process the information first.

Lastly, Attitude toward Green Brand positively influence Green Purchase Intention (t-value score 11.46). This result is in line with Mostafa (2007) in Huanget.al., (2014) who concluded that consumers' attitude has an important role in forming behavioral intention, and consumers with high level of attitude toward green products would form a strong desire toward green purchase intention. 


\section{Conclusion and Recommendations}

This research's findings provide some practical implications for research and business practices. The findings showed that Green Brand Positioning is the most important factor that might influence consumers' intention to buy green brands in personal care and cosmetics product category. Even though Green Brand Positioning does not influence Attitude toward Green Brand, but it influenced Green Brand Knowledge, which in turn will influence consumers' attitude and purchase intentions of green brands. Based on this result, companies need to pay attention on how they build their brands' positioning on consumers' mind using integrated and focused marketing communication strategy. The Body Shop needs to convey their environmentally related messages to the targeted consumers in ways that would interest consumers to learn more information about the brand's green efforts, and then The Body Shop must provide ways to engage consumers to learn more about the brand and its products. Among the things that the company could do is educating consumers on the natural ingredients that The Body Shop always use in its product. Using social media and store display would be an effective approach for the brand. Based on the demographic profile of respondents, $24 \%$ of respondents based their product choice on beauty bloggers/vloggers' recommendations. The Body Shop might develop some partnership with well-known bloggers/vloggers to educate consumers on the importance of using environmentally friendly personal care and cosmetics products.

This study still has some limitations. The respondents for this research was from Jakarta and greater area (Jabodetabek), which hardly would be the representative of Indonesia. The respondents of this research were young (17-21) and they were not working yet (high school and college students), which might impact their ability to purchase green brand personal care and cosmetics products, which usually priced higher than the average products. This might affect their judgment and pre-formed attitude towards The Body Shop.

Based on these limitations, extensive sampling is recommended to improve the generalizability of the research findings. To measure Green Brand Positioning, other variables such as personal character (e.g. Ecologically Conscious Consumer Behavior - ECCB) might be used since this might help in judging the effectiveness of green positioning strategy (Park et al., 1986 in Fuchs and Diamantopoulus, 2010).

\section{References}

Aaker, D.A. (1996). Building Strong Brands. The Free Press.

Aaker, D. A. Joachimsthaler, E. (2000). Brand Leadership. The Free Press, New York, NY

Becker-Olsen, K.L., Cudmore, B.A. Cudmore, R.P. (2006). The impact of perceived corporate social responsibility on consumer behavior. Journal of Business Research, 59 (1), 46-53.

Bhaskaran, P. M., Cary, J. Fernandez, S. (2006). Environmentally sustainable food production and marketing. British Food Journal, 108 (8), 677-690.

Building for The Future (2015). The Body Shop Values Performance Report. 
Chen, Y.S. (2008). The driver of green innovation and green image: Green core competence. Journal of Business Ethics, 8 (3), 531-543.

Chen, Y.S. (2012). Enhance green purchase intentions: The roles of green perceived value, green perceived risk, and green trust. Journal Management Decision., Vol. 50 No. 3 pp. 502-520.

Chen, Y.S. Chang, C.H. (2012). Enhance green purchase intentions: The roles of green perceived value, green perceived risk, and green trust. Management Decision, 50 (3), 502- 520 .

Clancy, K. J. Trout, J. (2002). Brand confusion. Harvard Business Review. https://hbr.org/2002/03/brand-confusion

Durif, F. Boivin, C. Julien, C. (2010). In search of green product definition. Innovative Marketing, 6 (1).

Doll, W.J. Xia, W. Torkzadeh, G. (1994) Confirmatory factor analysis of the end user computing satisfaction instrument. MIS Quarterly, December, pp 453-461.

Euromonitor Internasional. (2013). Dalam Indonesia Lahan Subur Industri Kosmetik. Kementerian Perindustrian Republik Indonesia. http://kemenperin.go.id/artikel/5897/ Indonesia-Lahan-Subur-IndustriKosmetik

Fuchs, C. Diamantopoulos, A. (2010). Evaluating the effectiveness of brand-positioning strategies from a consumer perspective. European Journal of Marketing, 44 (11/12), 1763- 1786.

Hair, J.F. Anderson, R.F. Tatham, R.I. Black, W.C. (1998). Multivariate Data Analysis, 5 ${ }^{\text {th }}$ edition. Prentice-Hall.

Hartmann, P. Ibanez, V. A. Sainz, J. F. (2005). Green branding effects on attitude: functional versus emotional positioning strategies. Marketing Intelligence \& Planning, 23 (1), 929.

Huang Y., Yang M., Wang Y. (2014). Effect of green brand on green puchase intention. Marketing Intelligence \& Planning, 32 (3), 250-268.

Igbaria, M. Zinatelli, N. Cragg, P. Cavaye, A.L.M. (1997). Personal computing acceptable factors in small firms: A structural equation model. MIS Quarterly, September, pp 279-299.

Keller, K. L. (1993). Conceptualizing, measuring, and managing customer-based brand equity. Journal of Marketing, 57 (1), 1-22.

Keller, K.L. (1998). Strategic Brand Management: Building, Measuring, and Managing Brand Equity. Prentice-Hall, Inc.

Laroche, M. Bergeron, J. Barbaro-Forleo, G. (2001). Targeting consumers who are willing to pay more for environmentally friendly products. Journal of Consumer Marketing, 18 (6), 503-520. 
Lee, K. (2008). Opportunities for green marketing young consumers. Marketing Intelligence \& Planning, 26 (6), 573-586.

Lubin, D.A. Esty, D.C. (2010). The sustainability imperative. Harvard Business Review, 88 (5), 42-50. https://hbr.org/2010/05/the-sustainability-imperative

Marcus, A. Fremeth, A.R. (2009). Green management matters regardless. Academy of Management Perspectives, 23 (3), 17-26.

Martin, B. Simintiras, A. C. (1995). The impact of green product lines on the environment. Marketing Intelligence Planning, 13 (4), 16-23.

Matthes, J. Wonnerberger, A. Schmuck, D. (2013). Consumers' green involvement and the persuasive effects of emotional versus functional ads. Journal of Business Research, 67(9), 1885-1893.

Moisander, J. (2007). Motivational complexity of green consumerism. International Journal of Consumer Studies, 31 (4), 404-416.

Oliver, J. D. Lee, S. (2010). Hybrid car purchase intentions: a cross-cultural analysis. Journal of Consumer Marketing, 27 (2), 96-103.

Patrick, H., Ibanez, V.A., Sainz, F.J.F. (2005). Green branding effects on attitude: functional vs emotional positioning strategies. Marketing Intelligence and Planning, 23 (1), 9-30. doi:

Raska, D. Shaw, D. (2012). When is going green for company image?. Management Research Review, 35 (3), 326-347.

Rehman, Z. Khyzer, M. (2013). Conceptualizing Green Purchase Intention in Emerging Markets: An Empirical Analysis on Pakistan. International Academic Conference Proceedings.

Rigdon, E.E. Ferguson, C.E. (1991). The performance of the polychoric correlation coefficient and selected fitting function in confirmatory factor analysis with ordinal data. Journal of Marketing Research, 28, November, pp 491-497.

Rios, F. J. M., Martinez, T. L., Moreno, F. F., Soriano, P. C. (2006). Improving attitudes toward brands with environmental associations: an experimental approach. Journal of Consumer Marketing, 23 (1), 26-33.

Seitz, V. Razzouk, N. Wells, D.M. (2010). The important of brand equity on purchasing consumer durable: an analysis of home air-conditioning systems. Journal of Consumer Marketing, 27 (3), 236-242.

Suki, N.M. (2016). Green product purchase intention: Impact of green brands, attitude, and knowledge. British Food Journal, Vol 118, Iss 12. 